ISSN 1119-7455

\title{
THE EFFECT OF THE EUROPEAN UNION (MPP6) INFRASTRUCTURAL DEVELOPMENT ON THE PRODUCTIVITY OF FOOD CROP FARMERS AND DEVELOPMENT OF RURAL AREAS IN IMO STATE
}

\author{
Uhuegbulem, I.J., Oguoma, N.N.O., Onyeagocha, S.U.O., Ehirim, N.C. and Henri-Ukoha*, A. \\ Department of Agricultural Economics, Federal University of Technology, \\ P.M.B. 1526, Owerri, Imo State, Nigeria \\ *Corresponding author's email: adanna.henri-ukoha@uniport.edu.ng
}

\begin{abstract}
The study examined the effect of the European Union infrastructural development on the productivity of food crop farmers and development of rural areas in Imo State. The specific objectives were to describe the socioeconomic characteristics of respondents, determine the extent of infrastructural development in the area and ascertain the impact of the scheme on the productivity of the rural food crop farmers. Primary data were collected with the aid of structured and validated questionnaire from 240 respondents comprising of farmers in the beneficiary and non-beneficiary communities using the multi-stage sampling technique. The data retrieved from the questionnaire were analysed with the use of the descriptive statistics, the infrastructural index model and the ordinary least squares regression model. The mean infrastructural index for the beneficiary and the non-beneficiary communities was 0.84 and 1.01, respectively; these figures were used to rank communities based on their level of development. The study showed that 18.2, 72.7 and $9.1 \%$ of the sampled beneficiary communities were developed, moderately developed and underdeveloped, respectively while 81.8 and $18.2 \%$ of the non-beneficiary communities were moderately developed and underdeveloped, respectively. The pooled result of the ordinary least square regression model showed a good fit at $p<0.05$, that a reduction in distance and cost of accessing the infrastructural facilities in the benefiting communities would increase food crop production in the area. The null hypothesis that the EU (MPP6) infrastructural facilities has no significant influence on the value of food crop production in the beneficiary communities was rejected as the F-cal obtained was greater than the F-tab at p 0.01 level. European Union through their Micro Project Programmes (MPP6) should expand it geographical scope to ensure that more infrastructural facilities are provided particularly in the non-beneficiary communities as this will bring about an increase in the productivity level of food crop farmers and the development of the rural areas.
\end{abstract}

Key words: rural infrastructure, agricultural productivity, infrastructural index, European Union Micro Project Program

\section{INTRODUCTION}

The main objectives of agricultural development are to increase productivity and income, diversify rural economy and generally enhance the quality of life of the rural farmers who are resident in the rural areas. In Nigeria, the rural areas are inhabited by the bulk of the national population. It is estimated that about $61 \%$ of the country's population are rural dwellers, and predominantly small scale farmers (World Resources, 1997), and over $90 \%$ of the Nigeria's total food produce comes from these small farmers and at least $60 \%$ of the nation's population earn their living from these small scale farming (Olayemi, 1980). However, larger percentage of these small scale farmers will remain poor unless basic infrastructures are provided in these rural areas (Ale et al., 2011).
Infrastructures are those underlying or basic forms of physical, social and institutional capital which enhance production and consumption activities and ultimately improved the wellbeing of rural communities. Rural infrastructures constitute the necessary components or ingredients for motivating rural residents to be more productive and achieve relative self-reliance (Ekong, 2005). Infrastructural facilities refer to those basic services without which primary, secondary and tertiary productive activities cannot function effectively (Hirschman, 1958). In other words, infrastructural facilities are elements in the package of basic needs, which a community would like to procure for better living (Olayiwola, 2005).

The role of infrastructural facilities in grassroots development and poverty reduction cannot be over-emphasized whether in urban or rural environments. McNeil (1993) shows that 
adequate infrastructure reduces the costs of production, which affects profitability, levels of output, and employment. When infrastructure works, productivity and labour increases. When it does not work, citizens suffer, particularly the poor. Thus, economic renewal and societal welfare become postponed or halted (Akinola, 2007). Infrastructures are key stimulants to agricultural development and growth (FAO, 1996). But most developing countries including Nigeria still suffer from inadequate rural infrastructural facilities (Olayiwola and Adeleye, 2005).

Even though Nigeria government initiated several projects to improve the quality and quantity of infrastructure in the rural areas through programmes such as the construction of small dams and boreholes for rural water supply and the clearing of feeder roads for the evacuation of agricultural produce, the supply of electricity to rural areas from large irrigation dams, the establishment of River Basin Development Authorities (RBDAs), Directorate for Food, Roads and Rural Infrastructure (DFRRI) and the Agricultural Development Programme the impact of such programmes on the lives of many rural people in the country is still considered to be limited (Ale et al., 2011). Studies have also shown that, despite all these developmental interventions, including the human and material resources devoted to the sector, the productive efficiency of most food crops farmers is still low as the few policies and programs initiated and implemented by successive government over the years have not resulted in meaningful enhancement of the development of the rural areas (Ezeah, 2005).

The neglect of rural infrastructural facilities (such as roads) has impeded the accessibility of farmers from sources of farm inputs, equipments and new technology, it has also reduced the profitability of agricultural production, marketing of agricultural commodities and prevents farmers from selling their produce at reasonable price due to spoilage (IFAD, 2011; Akpan, 2012) and this has invariably led to a decline in the income of the rural farmers and thus has led to an increase in their poverty status. According to World Bank survey (2002), about $70 \%$ of these Nigerians are poor, living on less than one dollar per day.

It was for this reason that the European Union (EU), through their Micro Project Programme in the six Niger Delta states (MPP6), intervened particularly in the areas of infrastructural development since, according to FAO (2005), rural infrastructure play crucial role in economic growth, poverty reduction and empowerment of the poor. Thus it is not certain, if the impact of the EU MPP6 has led to an increase in the productivity and development of the rural areas. Thus, the study sought to carry out an impact evaluation of the EU MPP6, aiming at determining whether the programme has achieved the desired outcome of increased productivity and rural development. The specific objectives were to; describe the socioeconomic characteristics of respondents, determine the extent of infrastructural development in the area and ascertain the effect of the scheme on the productivity of the rural food crop farmers.

\section{MATERIALS AND METHODS}

The study was carried out in Imo State. The state lies within latitude $5^{\circ} 40^{\prime}$ and $7^{\circ} 25^{\prime}$ north of the equator and Longitude $6^{\circ} 50^{\prime}$ and $7^{\circ} 25^{\prime}$ east of the meridian. The state covers a land area of $7,480 \mathrm{~km}^{2}$ with a population of $3,934,899$ (NPC, 2006). The state is characterized by tropical climate with high humidity and temperatures; rainfall and temperature ranges are $1500-2300 \mathrm{~mm}$ and $34-37^{\circ} \mathrm{C}$, respectively. The state is divided into three main agricultural zones namely Owerri, Okigwe and Orlu. It is further divided into 27 local government areas (LGAs). The main crops grown in the area include cassava, cocoyam, yam, maize, melon and vegetables. Imo State was purposively chosen for the study because it was among the six Niger Delta states that benefitted from the EU MPP6 and because of its proximity to the researcher.

\section{Sampling Technique and Data Collection}

The multi-stage sampling technique was employed in selecting the study sample. In the first stage, the state was stratified into three agricultural zones namely Owerri, Okigwe and Orlu. Secondly, from each of these zones, two LGAs were randomly selected making a total of six LGAs. In the third stage, four rural communities comprising of two beneficiary and two non-beneficiary communities were purposively selected from each of the selected LGAs, making a total of 24 autonomous communities. In the fourth stage, two villages were selected from each of the autonomous communities thereby given a total of 48 villages.

The sampling frame comprised the list of food crop farmers in each village within the selected autonomous communities who are registered with the state ADP. From the sampling frame, five farmers were randomly selected from each village thereby given a total of 240 farmers for both the beneficiary and non-beneficiary communities. A well structured and validated questionnaire was administered to all the selected farmers using the ADP enumerators in the area. The sampling was designed to generate a total of 240 respondents; however after data management only 220 questionnaire representing $91 \%$ were retrieved and used for the analysis. Data were collected from primary and secondary sources. The infrastructures considered were school, market, health, portable water and roads. Other information such as farmer's socio-economic features and income from farming activities were elicited. 


\section{Analytical Procedure}

The data were analyzed using descriptive statistics, the composite measure of infrastructure index and the ordinary least square regression model.

\section{The Composite Measure of Infrastructure Development}

The infrastructural index used here is based on the sampled communities' level data in line with Fakayode et al. (2008). The composite degree of infrastructure development used was adopted after Adeoye et al. (2011), Ashagidigbi et al. (2011), Balogun et al. (2012), Bulus and Adefila (2014), and Babatunde et al. (2014). It was obtained in a process listed in the equations below. Individual transportation cost (IDCi) of the respondents in each of the villages was taken as the sum of individual cost of access (TCi) to five basic infrastructure elements in this study. Average total cost (ATC) of getting to each of these infrastructure elements across these communities was computed and used to divide the average costs $(\mathrm{ACi})$ of getting to a particular facility in each of the communities. The outcome of this step $W i$ was summed up to obtain the infrastructural index $(I N F)$. The INF indicates the degree of underdevelopment; the higher the value of this index, the more under-developed the village is considered (Ahmed and Hossain, 1990):

$$
\begin{aligned}
& A C i=\frac{\sum_{i=1}^{n} I D C i}{n} \\
& T C i=\sum_{i=1}^{n} A C i \\
& A T C i=\frac{T C i}{N}
\end{aligned}
$$

$$
\begin{aligned}
& I N F=\sum_{i=1}^{n} W i \\
& W i=\frac{A C i}{A T C i}
\end{aligned}
$$

In these equations, IDCi is individual transportation cost of getting to each infrastructure by the respondents in each community ( $) ; C i$ is average cost of transportation in each community to a particular infrastructure (N); $T C i$ is total cost of transportation to a particular infrastructure across communities ( $)$; ATC is average cost of transportation to a particular infrastructure across communities (N); Wi is weight of average cost of transportation attached to infrastructure in each community; INF is infrastructural index; $N$ is total number of communities; and $n$ is number of respondents in each community.

\section{The Ordinary Least Square Regression Model}

This model was used to ascertain the effect of the EU infrastructural development on the value of productivity of food crop farmers in the beneficiary and non-beneficiary communities. The distance and cost of accessing these facilities were used as proxies to infrastructural index and the value of food crop production were all fitted into the model.

$\ln V F P i j=\&+\&_{1} \ln D s t i j+\&_{2} \ln C s t i j+u \quad 6$;

where VFPi is value of food crop production ( $)$; Dst is distance to infrastructure $(\mathrm{km})$; Cst is cost of accessing infrastructure ( $)$; $u$ is stochastic error term; $i$ is infrastructure, 1 for beneficiaries and 2 for non beneficiaries of intervention; $j$ is distance

\begin{tabular}{|c|c|c|c|c|c|}
\hline \multirow[t]{2}{*}{ Variable } & & \multicolumn{2}{|c|}{ Beneficiaries of MPP6 Intervention } & \multicolumn{2}{|c|}{ Non-beneficiaries of MPP6 Intervention } \\
\hline & & Freq & Percentage & Freq & Percentage \\
\hline \multirow[t]{5}{*}{ Age } & $31-40$ & 20 & 18.18 & 22 & 20.00 \\
\hline & $41-50$ & 24 & 21.82 & 28 & 25.46 \\
\hline & $51-60$ & 42 & 38.18 & 40 & 36.36 \\
\hline & 61 and above & 24 & 21.82 & 20 & 18.18 \\
\hline & Mean & 51.86 & & 50.77 & \\
\hline \multirow[t]{2}{*}{ Gender } & Male & 80 & 72.73 & 98 & 89.09 \\
\hline & Female & 30 & 27.27 & 12 & 10.91 \\
\hline \multirow[t]{5}{*}{ Household size } & $1-3$ & 14 & 12.73 & 22 & 20.00 \\
\hline & $4-6$ & 27 & 24.55 & 21 & 19.09 \\
\hline & $7-9$ & 52 & 47.27 & 44 & 40.00 \\
\hline & $10-12$ & 17 & 15.45 & 23 & 20.91 \\
\hline & Mean & 7 & & 6 & \\
\hline \multirow[t]{4}{*}{ Major occupation } & Farming & 65 & 59.09 & 66 & 60.01 \\
\hline & Trading & 21 & 19.09 & 18 & 16.36 \\
\hline & Civil servants & 16 & 14.55 & 16 & 14.54 \\
\hline & Artisan & 8 & 7.27 & 10 & 9.09 \\
\hline \multirow[t]{4}{*}{ Farm size } & $1-3$ & 85 & 77.27 & 81 & 73.64 \\
\hline & $4-6$ & 17 & 15.45 & 22 & 20.00 \\
\hline & $7-9$ & 7 & 6.36 & 7 & 6.36 \\
\hline & 10 and above & 1 & 0.92 & 0 & 0.00 \\
\hline \multirow[t]{4}{*}{ Educational attainment } & No formal education & 2 & 1.82 & 4 & 3.64 \\
\hline & Primary education & 48 & 43.64 & 51 & 46.36 \\
\hline & Secondary education & 37 & 33.64 & 31 & 28.18 \\
\hline & Tertiary education & 23 & 20.90 & 24 & 21.82 \\
\hline
\end{tabular}
and cost of accessing facilities whereby 1, 2, 3, 4 and 5 are for health, school, borehole, market and road facilities, respectively.

Table 1: Distribution of the respondents according to their socio-economic characteristics 


\section{RESULTS AND DISCUSSION}

Socio-Economic Characteristics of Respondents Table 1 shows the distribution of the respondents according to their socio-economic characteristics. From the table, the mean ages of the respondents in the beneficiary and non-beneficiary communities were 52 and 51 years, respectively, indicating that the respondents were at the active and productive stage of their life. This finding is consistent with that of Ibitoye et al. (2014). Majority of the respondents in the beneficiary and non-beneficiary communities (7 and 89\%, respectively) were males. The higher proportion of male implies that the male folk are more concerned about rural infrastructural development than the female folk in the study area.

Furthermore, the mean household size of the respondents in the beneficiary and non-beneficiary communities were 7 and 6 persons, respectively. The relatively large household size is an advantage in the area of provision of labour force for agricultural production in the study area. Majority of the respondents in the beneficiary and nonbeneficiary communities (59 and 60\%, respectively) had farming as their major occupation. This depicts the necessity to make rural life better through adequate provision of rural infrastructures. The study also found that majority of the respondents in the beneficiary and non-beneficiary communities (77 and $74 \%$, respectively) had farmlands between 1 and 3 ha, indicating that they were small-scale farmers producing at a subsistence level. Majority of the respondents in the beneficiary and nonbeneficiary communities (44 and $46 \%$, respectively) had attained primary education, indicating that the respondents in the area are moderately educated. This is consistent with the findings of Orebiyi et al. (2000) who opined that education is an investment in human capital which is able to raise the quality of skill of man, narrow his information gap and increase his allocative abilities thereby leading to more productive performance.
Infrastructural Index Estimation and Development Status of Communities in the Area The infrastructural index was computed to show the development status of communities with and without the EU MPP6 intervention. Table 2 shows that communities with the intervention had a mean infrastructural index with a standard deviation of $0.840 \pm 0.199$, while $1.01 \pm 0.284$ was obtained for communities without the intervention. The higher standard deviation of 0.284 in the non-beneficiary communities represents more divergent project locations, while a lower standard deviation of 0.199 in the beneficiary communities implies that the EU through their Micro Project Programme had converged infrastructures to the benefit of the rural people and thus a reflection of higher development status among the benefitting communities. Table 2 also shows that the mean infrastructural index for the communities with and without the EU MPP6 intervention were 0.840 and 1.01 , respectively. This implies that the communities with the intervention were more developed when compared with their counterpart. Also, among the communities with the EU MPP6 intervention, $18.2 \%$ were developed, $72.2 \%$ were moderately developed and $9.1 \%$ were underdeveloped. The high percentage rate of development was attributed to the presence of the intervention who had centrally located the various infrastructural facilities to the places where the distance and cost of accessing them is relatively better and cheaper.

For the communities without the EU MPP6 intervention, none of them was developed, $81.8 \%$ were moderately developed and $18.2 \%$ were underdeveloped. This percentage level of underdevelopment $(18.2 \%)$ suggests that access to various infrastructural facilities by the respondents were at a higher cost probably due to the far distance they had to cover in accessing the infrastructural facilities.

Table 2: Estimation of infrastructural index (inf. Index) and development status of communities with and without the European Union MPP6 infrastructural intervention

\begin{tabular}{|c|c|c|c|c|c|c|}
\hline \multirow{2}{*}{ Infrastructure } & \multicolumn{3}{|c|}{ Beneficiary Communities } & \multicolumn{3}{|c|}{ Non-Beneficiary Communities } \\
\hline & Community & Inf. Index & Development status & Community & Inf. Index & Development status \\
\hline Health centre & Achara & 0.900 & Moderately developed & Ehume & 1.507 & Under-developed \\
\hline Road & Alike & 0.909 & Moderately developed & Amanze & 0.909 & Moderately developed \\
\hline Health centre & Umuakagu & 0.900 & Moderately developed & Umunumo & 0.747 & Moderately developed \\
\hline Borehole & Ntu & 1.212 & Under-developed & Nguruumuaro & 1.280 & Moderately developed \\
\hline School & Eziama & 0.787 & Moderately developed & Umuekwunee & 0.923 & Moderately developed \\
\hline Borehole & Egbelu & 0.606 & Developed & Egbu & 0.732 & Moderately developed \\
\hline School & Ulakwo & 0.787 & Moderately developed & Awaka & 0.923 & Moderately developed \\
\hline Market & Amazu & 0.646 & Moderately developed & Amaeboebenato & 0.708 & Moderately developed \\
\hline Health centre & Umuhu Okabia & 0.530 & Developed & Assa & 0.821 & Moderately developed \\
\hline Market & Awalla & 1.011 & Moderately developed & Umuaghobe & 1.109 & Moderately developed \\
\hline Road & Umuduru & 0.982 & Moderately developed & Umulewe & 1.430 & Under-developed \\
\hline & Mean & 0.840 & & Mean & 1.010 & \\
\hline & Std. dev. & 0.199 & & Std. dev. & 0.284 & \\
\hline \multirow{3}{*}{\multicolumn{2}{|c|}{ Inf. Index Boundaries: }} & \multirow{3}{*}{\multicolumn{2}{|c|}{$\begin{array}{l}<0.641, \text { Developed }(18.2 \%) \\
0.642-1.039, \text { Moderately developed }(72.7 \%) \\
>1.039, \text { Underdeveloped }(9.1 \%)\end{array}$}} & & \multicolumn{2}{|c|}{$<0.726$, Developed $(0.00 \%)$} \\
\hline & & & & & \multirow{2}{*}{\multicolumn{2}{|c|}{$\begin{array}{l}\text { 0.727-1.294, Mod. developed }(81.8 \%) \\
>1.294, \text { Underdeveloped }(18.2 \%)\end{array}$}} \\
\hline & & & & & & \\
\hline
\end{tabular}




\section{Impact of the EU MPP6 on Food Crop Production} in Beneficiary and Non-Beneficiary Communities Table 3 shows the impact of accessing the EU MPP6 infrastructural development on the productivity of food crop farmers in the beneficiary communities as well as the impact of accessing similar infrastructural facilities on the productivity of food crop farmers in the non-beneficiary communities. The pooled results as shown in the table had a good fit at $p<0.05$ critical level of probability; this shows that at an aggregate level, a reduction in distance and cost of accessing the EU MPP6 in the benefiting communities would have an increasing effect on the value of food crop production in the area.

Table 3 also shows that distance to health and markets were significant and had an inverse effect on the value of food crop production in the benefitting communities. This implies that a reduction in distance to health facilities by $1.0 \%$ would give a more than proportionate increase in the value of food crop production by $2.145 \%$. Similarly, a reduction in the distance of accessing market facilities by $1.0 \%$ would give a more than proportionate increase in the value of food crop production by $1.359 \%$. Thus a reduction in the distance of accessing school, borehole and road facilities was not significant even at $10 \%$ probability level. This implies that a reduction in the distances of accessing these facilities would give a less than proportionate decrease in the value of food crop production in the study area.

Furthermore, the cost of accessing the MPP6 facilities behaved in the same manner; the cost of accessing health and market were significant and inversely related to the value of food crop production. Thus a reduction in the cost of accessing the health and market facilities by $1.0 \%$ would give a more than proportionate increase in the value of food crop production by $1.972 \%$ and $1.048 \%$. The pooled results had a good fit as the reductions in distance and cost of accessing MPP6 facilities were significant at 1 and $10 \%$ in the benefitting communities, while the reductions in the distances and cost of accessing the same facilities but not with the MPP6 intervention were not significant in the non-benefitting communities.

The null hypothesis that the EU MPP6 infrastructural development has no significant impact on food crop production in the beneficiary communities was rejected as the F-cal obtained was greater than the F-tab at $p<0.01$. It thus follows that EU MPP6 infrastructural development has significant effect on the value of food crop production in the beneficiary communities.

\section{Conclusion and Recommendation}

Findings of the study reveal that the communities with the European Union Micro Project Programmes (EU MPP6) as form of infrastructural intervention

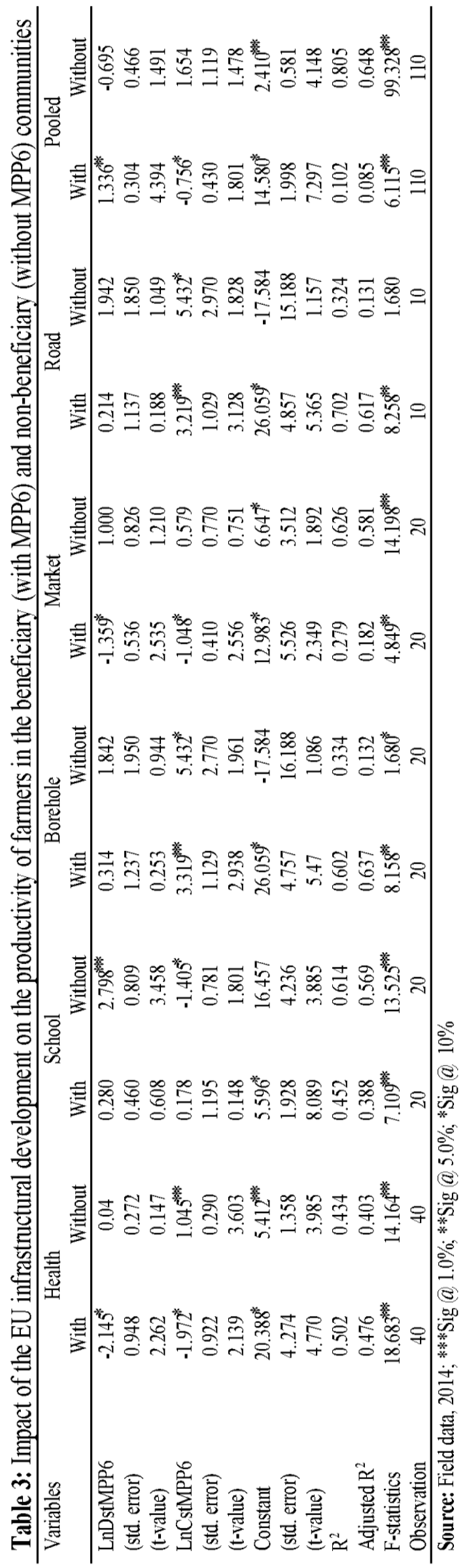


had a lower infrastructural index of 0.840 and they were more developed when compared with their counterparts in the non-beneficiary communities. The pooled results of the ordinary regression model also reveal that at an aggregate level, a reduction in the distance and cost of accessing the EU MPP6 infrastructural facilities would have an increasing effect on the value of food crop production.

The study recommends that the EU through their Micro Project Programme should establish more infrastructural facilities particularly in the communities where they have not intervened as this would bring about the development of the rural areas. The EU should also consider widening its scope of operation to include direct investment in agricultural production such as the provision of credit facilities to farmers, rural electrification, provision of fertilizers, provision of processing and storage facilities, etc. This is necessary because agricultural production remains the major economic activity of the rural people.

\section{REFERENCES}

Adeoye, A., Yusuf, S.A., Balogun, O.L., Carim-Sanni, A. (2011). Rural infrastructural development and profitability of famers under Fadama-II Project in Oyo State, Nigeria. World Rural Observation, 3 (2), $1-10$

Ahmed, R. and Hossain M. (1990). Developmental Impact of Rural Infrastructure in Bangladesh. Research Report 83. Washington D.C., International Food Policy Research Institute

Akinola, S.R. (2007). Coping with infratructural deprivation through collective action among rural people in Nigeria. Normadic Journal of African Study, 16(1), 30-46

Akpan, N.S. (2012). From agriculture to petroleum oil production: What has changed about Nigeria's rural development? International Journal of Developing Societies, 1(3), 97-106
Ale, M.O., Abisuwa, T.A., and Ologunagba, F.O. (2011). Rural infrastructural development, food security and city congestion in Nigeria. Journal of Research in National Development, 1 (9), 124-130

Ashagidigbi, W.M., Abiodun, O.F., and Samson, O.A. (2011). The effects of rural infrastructure development on crop farmer's productivity in Osun State. World Rural Observations, 3 (1), 48-58

Babatunde, R.O., Adenuga, A.H., Olagunju, F.I., and Oladoja, A.O. (2014). Effect of road infrastructure on farm production in Oyo State, Nigeria. Ethiopian Journal of Environmental Studies and Management, 7 (2), 197-201

Balogun, O.L, Adeoye, A., Yusuf, S.A., Akinlade, R.J., and Carim, S.A. (2012). Production efficiency of farmers under national Fadama II Project in Oyo State, Nigeria. International Journal of Agricultural Management and Development, 2 (1), 11-24

Bulus, J.S., and Adefila, J.O. (2014). The study of rural infrastructural facilities in Kajuru area, Kaduna State of Nigeria: A spatial analysis for planning. International Journal of Humanities and Social Science, 4 (2), 286-295

Ekong, E.E. (2005). Rural Sociology; An Introduction and Analysis of Rural Nigeria (Revised Edition). Dove Educational Publishers, Uyo Nigeria

Ezeah, P. (2005). Rural Sociology and Rural Development with Focus on Nigeria. Enugu: John Jacob Classic Publishers

Fakayode, B.S., Omotesho, O.A, Tsoho, A.B., and Ajayi, P.D. (2008). An economic survey of rural infrastructures and agricultural productivity profiles in Nigeria. European Journal of Social Sciences, 7 (2), 158-171

FAO (1996). Funding agricultural research in selected countries of sub-Saharan Africa. http://www.fao.org/sd.indexen.htm

FAO (2005). Comprehensive Africa Agricultural Development Programme. FAO Corporate Document Repository 